\title{
Response of broilers to supplementation of branched-chain amino acids blends with different valine contents in the starter period under summer conditions
}

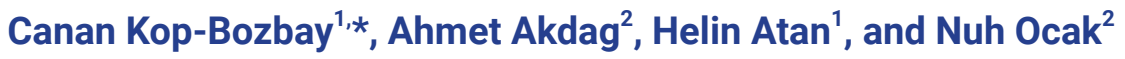

\author{
* Corresponding Authors: Canan Kop-Bozbay \\ Tel: +90-222-324-29-91/4884 \\ Fax: +90-222-324-29-90, \\ E-mail: cbozbay@ogu.edu.tr \\ ${ }^{1}$ Department of Animal Science, Faculty of \\ Agriculture, Eskisehir Osmangazi University, \\ 26480, Eskisehir, Turkey \\ ${ }^{2}$ Department of Animal Science, Faculty \\ of Agriculture, Ondokuz Mayis University, \\ 55139, Samsun, Turkey \\ ORCID \\ Canan Kop-Bozbay \\ https://orcid.org/0000-0002-8071-5860 \\ Ahmet Akdag \\ https://orcid.org/0000-0001-7828-462X \\ Helin Atan \\ https://orcid.org/0000-0003-3574-2891 \\ Nuh Ocak \\ https://orcid.org/0000-0001-7393-1373
}

Submitted Oct 21, 2019; Revised Dec 21, 2019; Accepted Feb 19, 2020
Objective: The objectives of this study were to compare the effects of normal and low protein content (PC) of starter diet supplemented or not with blends of branched-chain amino acids (BCAAs) on growth performance of broilers under summer conditions and to investigate whether these effects altered some quality traits and the characteristics of gastrointestinal tract.

Methods: A total of 768 mixed-sex broiler chicks (Ross 308, one-d-old) with an average initial body weight (BW) of $47.6 \pm 1.03 \mathrm{~g}$ were allocated into six treatments with four replications in $2 \times 3$ factorial arrangement. Factors were: PC, normal (N, 22\% to d 15); and low (L, 20\% to d 15); and added BCAA blends, L-leucine, L-isoleucine, and L-valine at zero (0L:0I:0V); 1.0, 0.25, and 0.25 (4L:1I:1V); or 1.0, 0.25, 0.75 (4L:1I:3V) g/kg of diet. Hence, six dietary treatments were named as N0L:0I:0V, N4L:1I:1V, N4L:1I:3V, L0L:0I:0V, L4L:1I:1V, and L4L:1I:3V. Average indoor temperature and humidity were $32.8^{\circ} \mathrm{C} \pm 1.7^{\circ} \mathrm{C}$ and $61.1 \%$ $\pm 4.12 \%$, respectively.

Results: BW, feed conversion ratio (FCR) and carcass weight were not affected by PC, BCCA and their interaction $(\mathrm{p}>0.05)$. The $\mathrm{L}$ diets decreased the water holding capacity of the breast $(\mathrm{p}=0.002)$ and thigh $(\mathrm{p}=0.050)$ meats and dressing percentage $(\mathrm{p}=0.005)$ compared to the $\mathrm{N}$ diets. The $4 \mathrm{~L}: 1 \mathrm{I}: 1 \mathrm{~V}$ diet decreased breast yield compared to the $0 \mathrm{~L}: 0 \mathrm{I}: 0 \mathrm{~V}$ diets $(\mathrm{p}=$ 0.041). The effect of PC on feed intake, mortality and gastrointestinal trait weight were depended on the L:I:V ratios under summer conditions due to interactions between factors $(\mathrm{p}<0.05)$. The FI and mortality of L4L:1I:1V broilers were lower than those of N4L:1I:1V birds $(\mathrm{p}<0.05)$.

Conclusion: It was concluded that the blends of BCAAs used failed to improve performance and to promote breast yields, because diets with normal or with reduced protein supplemented or not with BCAAs up to $\mathrm{d} 15$ produced a similar BW and FCR in broilers raised in hot-climate conditions.

Keywords: Poultry; Amino Acids; Productive Performance; Carcass Yield; Digestive System; Muscle Growth; Meat Quality

\section{INTRODUCTION}

Optimal growth rate, feed intake (FI) and thereby feed conversion ratio (FCR) in broiler chickens require dietary crude protein $(\mathrm{CP})$ with optimum amino acids (AAs) composition during early stages of growth. Such dietary protein sources are the most expensive ingredients for poultry diets. Therefore, one of the greatest challenges to the efficient production of broilers is lack of AAs resulting in a delay in the development of gastrointestinal tract (gut) and proliferation of muscle cells associated with early protein supply [1]. Indeed, the final growth rates of broilers are directly proportional to the early growth rate of its skeletal muscles and especially gut [2]. Therefore, there is a trend towards the reduction of CP con- 
tent (PC) in broiler diets [1,3,4]. Commercial branched-chain amino acids (BCAAs) supplements may allow the dietary CP level to reduce [5-7], because leucine, isoleucine and valine are not merely three of the nine essential AAs for poultry, but also are proteinogenic AAs that are regulated protein synthesis in a variety of tissues [8]. As such, the BCAAs supplements may improve the development of gut and proliferation of muscle cells during early stages of growth while overcoming some problems such as cost of production and soil pollution associated with the protein nutrition $[5,9,10]$.

Effects of exogenous nutrients on the development of gut and muscle in broiler chicks may be more effectively examined during early stages of growth [8]. At this period, low$\mathrm{CP}$ diets supplemented or not with BCAAs either as single or combined mixtures for broilers have, therefore, been the subject of extensive studies [5-7]. However, there are discrepancies among the findings of these studies. Because there are interactions among the BCAAs, an increase in its activity (i.e. due to leucine excess) increases the catabolism of the three BCAAs, in case of valine and isoleucine deficiencies a high dietary leucine content may have caused an increase in valine and isoleucine requirements of broilers $[5,7,11]$. Moreover, this effect of leucine is more potent on valine than on isoleucine in environmentally controlled houses [5]. Therefore, the anti-proteolytic or anti-catabolic effect of leucine is promoted in the presence of valine and isoleucine [12]. Although feeding low-CP diets while adding more crystalline BCAAs (in particular valine and isoleucine) than that required to broiler diets during early ages has gained importance $[6,11,13,14]$, the response of broilers to blends of BCAAs with different valine contents is not well defined in the hot-climatic conditions.

A reduction in FI of broilers reared in hot-climate region could change the partition and utilization of AAs in the metabolism of birds due to reduced protein intake $[10,11]$. Dietary valine has decreased the negative effect of feeding low-CP diets in broiler chickens through the beneficial effect on protein accretion and intestinal morphology $[6,13]$. Therefore, we hypothesised that during the first two weeks, the mixture of BCAAs with increased content of valine may provide an opportunity to reduce the $\mathrm{CP}$ of the broiler starter diet and to mitigate the effects of heat stress from summer conditions on growth performance. Consequently, these may change carcass yield, the characteristics of non-carcass parts and meat quality. Accordingly, the objectives of this study were to compare the effects of normal and low-PC of starter diet supplemented or not with blends of BCAAs on growth performance of broilers under summer conditions and to investigate whether these effects altered some quality traits of breast and thigh (leg quarters) meats, liver colour values and the characteristics of whole gut and its some segments.

\section{MATERIALS AND METHODS}

\section{Animal care and study site}

This study, conducted between June and July 2017, was carried out at the Research Farm of Agricultural Faculty of Eskisehir Osmangazi University in Eskisehir, Turkey (39 $45^{\prime} 42^{\prime \prime} \mathrm{N}$ and $30^{\circ} 28^{\prime} 40^{\prime \prime} \mathrm{E}$, and altitude of $813 \mathrm{~m}$ above sea level). The study was approved by the local Ethics Committee for Experimental Animals, which ascertained that the experiment was not an unnecessary repetition of previous experiments (case number: HAYDEK-582/2017).

\section{Animals, diets, and management}

A total of 768 one-d-old chicks (Ross 308) obtained from a commercial hatchery (Ross Breeders, Inegol, Turkey) were weighed. The sex of each chick was determined according to the difference in design and size of flight feathers on the wings of males and females in the first days after hatching. Then, they were allocated into six treatments (128 mixed-sex broilers each) according to initial body weight (average 47.6 \pm 1.03 $\mathrm{g} /$ chick) in $2 \times 3$ factorial arrangement. Each treatment had four replicated pens with 32 birds ( 16 females and 16 males) per pen, which was considered as an experimental unit. Factors were: PC, normal (N, 22\% to d 15) and low (L, 20\% to d 15), and added blends of BCAAs (BCAA), graded levels of L-leucine (Cas no: 61-90-5), L-isoleucine (Cas no: 72-18-4), and L-valine (Cas no: 73-32-5) were supplemented to the $\mathrm{N}$ and L diets at zero (0L:0I:0V), 1.0, 0.25 and 0.25 (4L:1I:1V) or $1.0,0.25,0.75$ (4L:1I:3V) g/kg of diet, accomplished by adding the blends of these AAs at the expense of an inert filler. Hence, six dietary treatments were named as N0L:0I:0V, N4L:1I:1V, N4L:1I:3V, L0L:0I:0V, L4L:1I:1V, and L4L:1I:3V. Broiler starter diets were formulated according to the management guide for Ross 308 [15] to contain $220 \mathrm{~g} \mathrm{CP}$ and $3,050 \mathrm{kcal}$ metabolizable energy (ME)/kg in starter diets, and $200 \mathrm{~g} \mathrm{CP}$ and 3,200 kcal ME/kg in grower diets (Table 1). The content of standardized available AAs in all diets [16] was similar (Table 2). The feeding program had two phases: starter (d 1 to 21 ) and grower (d 22 to 42 ). From 16 to 42 days of age, all birds were fed following the relevant feeding program recommended in the management guide for Ross 308 broiler [15].

During the entire experiment, all chicks were reared on the floor pens $(2.5 \mathrm{~m}$ length $\times 1.0 \mathrm{~m}$ width $\times 4.5 \mathrm{~m}$ height $)$ littered with wood shavings. All feeds (mash form) and water were provided ad libitum using red circular poultry feeder plates and automatic drinkers. Artificial light provided by two 125 -watt bulb lamps was continuous in the first week and 23 hours afterwards. The experiment was performed under standard husbandry practices, except for ambient temperature. This study was carried out in summer environmental conditions (Figure 1). However, because am- 
Table 1. Ingredients and calculated nutrient values of the basal diets with normal $(\mathrm{N})$ and low $(\mathrm{L})$ protein ${ }^{1)}$ (as-fed basis)

\begin{tabular}{|c|c|c|c|}
\hline Items & $\mathrm{N}$ starter (1 to $21 \mathrm{~d})$ & L starter ( 1 to $21 \mathrm{~d}$ ) & Grower (22 to $42 \mathrm{~d}$ ) \\
\hline \multicolumn{4}{|l|}{ Ingredients (g/kg) } \\
\hline Corn (8.2\% crude protein) & 516.0 & 587.9 & 623.0 \\
\hline Soybean meal (46\% crude protein) & 388.9 & 325.0 & 313.0 \\
\hline Soybean oil & 59.1 & 47.3 & 38.0 \\
\hline Dicalcium phosphate & 16.2 & 17.5 & 11.0 \\
\hline Limestone & 9.8 & 9.3 & 7.5 \\
\hline DL-methionine (99.0\%) & 1.7 & 2.4 & 2.0 \\
\hline L-threonine (98.5\%) & - & 0.5 & - \\
\hline Vitamin and mineral premix ${ }^{3)}$ & 3.5 & 3.5 & 2.5 \\
\hline \multicolumn{4}{|c|}{ Calculated energy $(\mathrm{kcal} / \mathrm{kg})$ and nutrient contents $(\mathrm{g} / \mathrm{kg})$} \\
\hline Metabolizable energy & 3,050 & 3,050 & 3,200 \\
\hline Available P & 4.7 & 4.7 & 4.0 \\
\hline Lysine & 12.7 & 12.8 & 10.8 \\
\hline Methionine+cysteine & 10.4 & 10.0 & 9.7 \\
\hline \multicolumn{4}{|c|}{$\begin{array}{l}\text { 1) Up to } 15 \mathrm{~d} \text { of age, L-leucine, L-isoleucine, and L-valine were added to the starter diets with the } \mathrm{N} \text { and L protein contents at zero, } 1.0,0.25 \text { and } 0.25 \text { or } 1.0 \text {, } \\
0.25,0.75 \mathrm{~g} / \mathrm{kg} \text { of diet, respectively. Supplemental BCAA blends were added to the test diets at the expense of the inert filler to derive dietary treatments. } \\
\text { 2) To estimate dietary protein, crude protein values of all amino acids were considered [16]. } \\
\text { 3) Supplied per kilogram of diet: vitamin } \mathrm{A}, 12,000 \mathrm{IU} \text {; vitamin } \mathrm{D}_{3}, 2,400 \mathrm{IU} \text {; vitamin } \mathrm{E}, 30 \mathrm{IU} \text {; vitamin } \mathrm{K}_{3}, 2.5 \mathrm{mg} \text {; vitamin } \mathrm{B}_{1}, 3.0 \mathrm{mg} \text {; vitamin } \mathrm{B}_{2}, 7 \mathrm{mg} \text {; nicotine } \\
\text { amid, } 40 \mathrm{mg} \text {; calcium D-pantothenate, } 8.0 \mathrm{mg} \text {; vitamin } \mathrm{B}_{6}, 4.0 \mathrm{mg} \text {; vitamin } \mathrm{B}_{12}, 0.015 \mathrm{mg} \text {; folic acid, } 1 \mathrm{mg} \text {; D-biotin, } 0.045 \mathrm{mg} \text {; vitamin } \mathrm{C}, 50 \mathrm{mg} \text {; choline chlo- } \\
\text { ride, } 270 \mathrm{mg} \text {; Mn, } 80 \mathrm{mg} \text {; Fe, } 40 \mathrm{mg} ; \mathrm{Zn}, 60 \mathrm{mg} \text {; Cu, } 5 \mathrm{mg} \text {; Co, } 0.1 \mathrm{mg} \text { I. } 0.4 \mathrm{mg} \text {; Se, } 0.15 \mathrm{mg} \text {. }\end{array}$} \\
\hline
\end{tabular}

bient temperature was $33^{\circ} \mathrm{C} \pm 1^{\circ} \mathrm{C}$ during the brooding period (the first two weeks), chicks were not exposed to any heat stress. From d 15, all the birds were exposed to high temperature $\left(36^{\circ} \mathrm{C} \pm 1.2^{\circ} \mathrm{C}\right)$ and humidity $(70 \% \pm 2.5 \%)$ for $3 \mathrm{~h}$ from 11:00 to $14: 00$ every day until the end of the experiment due to outdoor temperature and humidity. However, average weekly temperature and humidity in the indoor during the experiment could be kept at $32.8^{\circ} \mathrm{C} \pm 1.7^{\circ} \mathrm{C}$ and
$61.1 \% \pm 4.12 \%$, respectively. After the heat challenge, the time required to decrease the temperature from $36^{\circ} \mathrm{C}$ to $24^{\circ} \mathrm{C}$ was $1 \mathrm{~h} 30 \mathrm{~min}$.

\section{Feed intake and growth performance}

The broilers were weighed on a pen basis at periods corresponding to the treatment phases (at 15 and $42 \mathrm{~d}$ of age), while FI was recorded on $\mathrm{d} 7,14,21,28,35$, and 42 . These were

Table 2. Calculated available amino acid values of experimental diets

\begin{tabular}{|c|c|c|c|c|c|c|}
\hline Amino acids $(\mathrm{g} / \mathrm{kg})^{1)}$ & NOL:OI:OV') & N4L:1I:1V & N4L:1I:3V ${ }^{2}$ & LOL:OI:OV & L4L:1I:1V V) & L4L:1I:3V ${ }^{2}$ \\
\hline Lysine & 12.70 & 12.70 & 12.70 & 12.80 & 12.80 & 12.80 \\
\hline Methionine & 4.70 & 4.70 & 4.70 & 4.70 & 4.70 & 4.70 \\
\hline Methionine+cysteine & 8.30 & 8.30 & 8.30 & 8.30 & 8.30 & 8.30 \\
\hline Arginine & 14.20 & 14.20 & 14.20 & 14.20 & 14.20 & 14.20 \\
\hline Phenylalanine & 1.03 & 1.03 & 1.03 & 1.03 & 1.03 & 1.03 \\
\hline Tyrosine & 8.40 & 8.40 & 8.40 & 8.40 & 8.40 & 8.40 \\
\hline Threonine & 8.10 & 8.11 & 8.11 & 8.10 & 8.11 & 8.11 \\
\hline Tryptophan & 2.90 & 2.90 & 2.90 & 2.90 & 2.90 & 2.90 \\
\hline Leucine & 18.70 & 19.70 & 19.70 & 18.70 & 19.70 & 19.70 \\
\hline Isoleucine & 9.00 & 9.25 & 9.25 & 9.00 & 9.25 & 9.25 \\
\hline Valine & 10.00 & 10.25 & 10.75 & 10.00 & 10.25 & 10.75 \\
\hline
\end{tabular}

\footnotetext{
1) The available amino acids contents of all diets were calculated basing the values tabulated for individual feedstuffs [16].

2) NOL:Ol:OV, the starter diets (22\% to d 15) with the normal protein content (PC), added L-leucine, L-isoleucine, and L-valine at zero (0L:0l:0V); N4L:1:1V, the starter diets with the normal PC added L-leucine, L-isoleucine, and L-valine at 1.0, 0.25, and 0.25 (4L:11:1V) g/kg of diet; N4L:1l:3V, the starter diets with the normal PC added L-leucine, L-isoleucine, and L-valine at 1.0, 0.25, and 0.75 (4L:1l:3V) g/kg of diet; LOL:0l:0V, the starter diets (20\% to d 15) with the low PC added L-leucine, L-isoleucine, and L-valine at zero; L4L:1l:1V, the starter diets with the low PC added L-leucine, L-isoleucine, and L-valine at 1.0, 0.25, and 0.25 (4L:1l:1V) g/kg of diet; L4L:1l:3V, the starter diets with the low PC added L-leucine, L-isoleucine, and L-valine at 1.0, 0.25, and 0.75 (4L:1l:3V) g/kg of diet.
} 


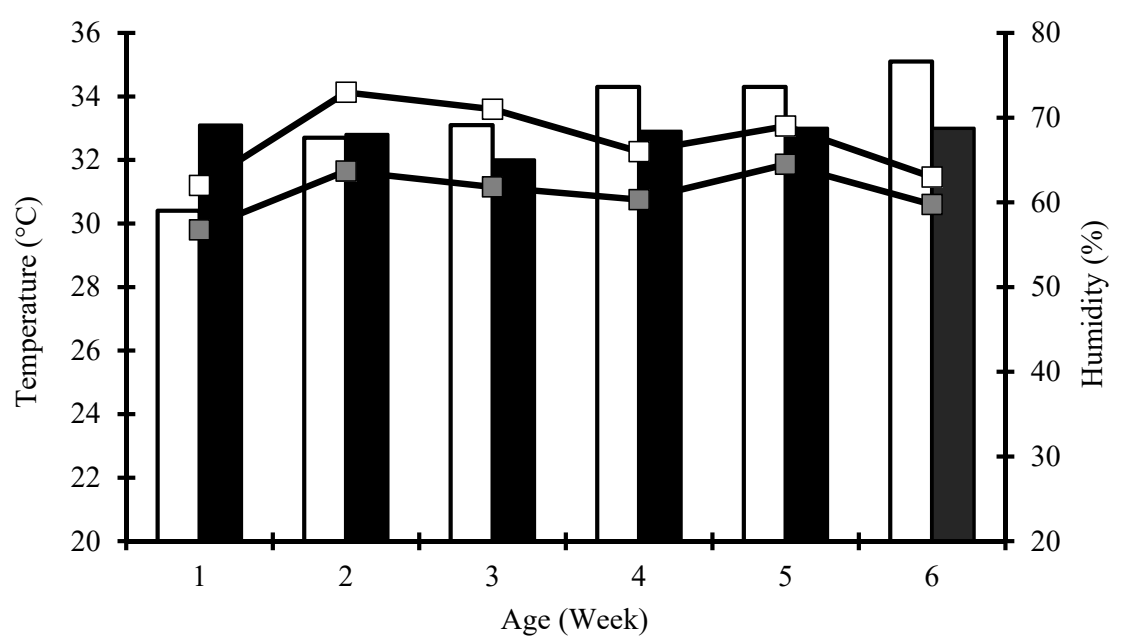

Figure 1. Average weekly temperature (bar) and humidity (line) in the outdoor ( $\square$ ) and indoor $(\mathbf{\square})$ during the experiment.

then used to calculate daily body weight gain (BWG) and FI. Health status of birds was monitored at least twice daily. The gender, number and weight of dead birds found at these inspections were recorded to calculate mortality and FCR ( $g$ feed:g gain) corrected for mortality. Therefore, it was made to adjust the data as per numbers of males and females in each pen on weigh days and FCR was calculated by adding the weight of dead birds.

\section{Carcass characteristics and the size of internal organs}

On $\mathrm{d} 14$ and 42, after $10 \mathrm{~h}$ fasting and free access to feed, four birds with BW within one standard deviation of the mean treatment weight were slaughtered humanely and chilled at $4^{\circ} \mathrm{C}$ for $12 \mathrm{~h}$. The influences of gender were not determined on the studied parameters. To determine weights of carcass and metabolically active organs (liver, heart, pancreas, whole gut and its segments) and tissues (breast and thigh muscles), abdominal cavities of all carcasses were opened and then, they were carefully removed and weighed after its contents were cleaned $[12,17]$. The small intestine was carefully dissected from the mesentery and divided into its segments as duodenum, jejunum and ileum [6]. Carcass yield that expressed as dressing percentage and relative weights of organ and tissue were calculated using the BW just before slaughter of the broilers and thus expressed as a percentage of BW just before slaughter (g/100 g BW).

\section{Meat quality traits}

On d 42, nutritional and visual quality characteristics of skeletal muscles and the colour values of the liver were also determined. The samples from the raw breast and thigh meats were mashed and dry matter (DM; method 930.15), ash (method 942.15), CP (method 990.03) and ether extract (EE, method 920.39) were performed in triplicate according to the approved methods [18]. Proximate analysis results were expressed in wet basis. The Commission Internationale de l'Eclairage $\mathrm{L}^{*}$ (lightness), $\mathrm{a}^{*}$ (redness), and $\mathrm{b}^{*}$ (yellowness) values (CIELab) were measured $24 \mathrm{~h}$ after the slaughter using a Minolta CR 300 Chroma Meter (Minolta Camera, Osaka, Japan). Four and three replicate measures on the meat and liver samples, respectively, were made and expressed as the mean CIELab values calculated for each sample [12]. To determine water holding capacity (WHC) of breast and thigh meats, meat cubes of $1 \mathrm{~g}$ were rolled with filter paper and put into Eppendorf tubes and centrifuged for $4 \mathrm{~min} \times$ $1,500 \mathrm{~g}$ [19]. The samples removed from the papers were weighed and then, the weight difference between the initial and final weight of samples was calculated. The WHC values were expressed as the percentage of drip loss relative to the initial sample weight.

\section{Statistical analysis}

The experiment was designed as a $2 \times 3$ factorial and the data were analyzed using the general linear model procedure in SPSS Release 21.0 (SPSS Inc., Chicago, IL, USA) in the model as follows:

$$
Y_{\mathrm{ijk}}=\mu+P_{\mathrm{i}}+B_{\mathrm{j}}+P B_{\mathrm{ij}}+e_{\mathrm{ijk}}
$$

Whereas $Y_{\mathrm{ijk}}$ is the feeding effect on birds, $\mu$ was the mean value, $P_{\mathrm{i}}$ is an effect of $\mathrm{PC}, B_{\mathrm{j}}$ is the effect of BCAA, $P B_{\mathrm{ij}}$ is the interaction of the PC and BCAA factors, and $e_{\mathrm{ijk}}$ is the error value. Data regarding mortality, relative organ weights were analyzed after arcsine transformation $[(\% \text { data/100 })+0.05]^{0.5}$. Normality and homoscedasticity of these data were verified by Levene's test (SPSS Inc., USA). The significant differences among means were analyzed by using the Tukey test and were deemed significant at $\mathrm{p}<0.05$. 


\section{RESULTS}

\section{The effect of crude protein content}

The BWG, FCR, and carcass weight of broiler chickens were not affected by the PC treatment at 14 and $42 \mathrm{~d}$ of age (Table 3). Compared to the $\mathrm{N}$ diet, the $\mathrm{L}$ diet decreased the dress- ing percentage $(\mathrm{p}=0.002)$ on $\mathrm{d} 42$ (Table 3$)$, the pancreas weight $(p=0.005$, Table 4$)$ and the protein concentration of thigh meat $(\mathrm{p}=0.023$, Table 5$)$ on $\mathrm{d} 14$. The $\mathrm{L}$ diet increased the pancreas weight $(\mathrm{p}=0.005)$ on $\mathrm{d} 14$ (Table 4$)$ and the WHC of the breast $(\mathrm{p}=0.002)$ and thigh $(\mathrm{p}=0.050)$ meats on d 42 (Table 6).

Table 3. The growth performance, mortality, carcass weight and dressing percentage of broilers fed starter diets with different levels of protein and blends of branched-chain amino acids under hot summer conditions

\begin{tabular}{|c|c|c|c|c|c|c|c|c|c|}
\hline \multirow{2}{*}{ Variable } & \multicolumn{2}{|c|}{$P C^{1)}$} & \multicolumn{3}{|c|}{ BCAA $^{1)}$} & \multirow{2}{*}{ SEM } & \multicolumn{3}{|c|}{ Main effect of } \\
\hline & $\mathbf{N}$ & $\mathbf{L}$ & OL:OI:OV & 4L:1I:1V & 4L:1I:3V & & PC & BCAA & PCXBCAA \\
\hline \multicolumn{10}{|l|}{ On $14 \mathrm{~d}$ of age } \\
\hline Body weight gain $(\mathrm{g} / \mathrm{bird} / \mathrm{d})^{2)}$ & 26.24 & 25.97 & 26.38 & 26.59 & 26.07 & 0.280 & ns & ns & ns \\
\hline Feed intake (g/bird/d) & 39.26 & 38.75 & 39.25 & 39.02 & 38.74 & 0.237 & ns & ns & ns \\
\hline Feed conversion ratio (g feed:g gain) & 1.49 & 1.49 & 1.48 & 1.46 & 1.48 & 0.008 & ns & ns & ns \\
\hline Mortality (\%) & 1.30 & 1.82 & 2.73 & 1.17 & 1.17 & 0.459 & ns & ns & ns \\
\hline Carcass weight $(\mathrm{g})^{3)}$ & 274.05 & 276.11 & 284.06 & 277.12 & 273.20 & 5.750 & ns & ns & ns \\
\hline Dressing percentage (\%) & 62.57 & 63.55 & 63.87 & 62.92 & 62.31 & 0.400 & ns & ns & ns \\
\hline \multicolumn{10}{|l|}{ On $42 \mathrm{~d}$ of age } \\
\hline Body weight gain $(\mathrm{g} / \mathrm{bird} / \mathrm{d})^{2)}$ & 58.48 & 58.36 & 59.06 & 58.43 & 57.76 & 0.434 & ns & ns & ns \\
\hline Feed intake (g/bird/d) & 107.90 & 107.98 & 109.24 & 106.79 & 107.80 & 1.046 & ns & ns & * \\
\hline Feed conversion ratio (g feed:g gain) & 1.84 & 1.85 & 1.84 & 1.82 & 1.86 & 0.016 & ns & ns & ns \\
\hline Mortality (\%) & 7.03 & 7.03 & 7.81 & 6.64 & 5.85 & 0.834 & ns & ns & * \\
\hline Carcass weight $(\mathrm{g})^{3)}$ & $2,057.5$ & $2,016.2$ & $2,048.6$ & $2,055.0$ & $2,009.2$ & 25.51 & ns & ns & ns \\
\hline Dressing percentage (\%) & $78.41^{\mathrm{a}}$ & $77.09^{b}$ & 77.70 & 77.73 & 77.83 & 0.199 & $\star \star$ & ns & ns \\
\hline
\end{tabular}

SEM, standard error of the mean.

1) PC, crude protein content of starter diets; BCAA, added blends of branched-chain amino acids; N, starter diet (22\% to d 15) formulated with normal crude protein; L, starter diet formulated ( $20 \%$ to d 15 ) with low crude protein; OL:0l:0V, diet without of BCAA blends; 4L:1l:1V, diet added L-leucine, L-isoleucine, and L-valine at 1.0, 0.25, and $0.75 \mathrm{~g} / \mathrm{kg} ; 4 \mathrm{~L}: 11: 3 \mathrm{~V}$, diet added L-leucine, L-isoleucine, and L-valine at 1.0, 0.25, and 0.75 g/kg.

2) The values are means of the four replicates with 32 birds per treatment.

3) The values are means of the four replicates with two birds per treatment.

${ }^{a b}$ Within a row, means with different superscripts differ significantly $(p<0.05)$.

ns, nonsignificant; $p>0.05 ;{ }^{*} p<0.05 ; * \star p<0.01$.

Table 4. The relative weight of some organs and meats ( $\mathrm{g} / 100 \mathrm{~g} \mathrm{BW}$ ) of broilers fed starter diets with different levels of protein and blends of branched-chain amino acids under hot summer conditions

\begin{tabular}{|c|c|c|c|c|c|c|c|c|c|}
\hline \multirow{2}{*}{ Variable $^{1)}$} & \multicolumn{2}{|c|}{$\mathrm{PC}^{2)}$} & \multicolumn{3}{|c|}{$\mathrm{BCAA}^{2)}$} & \multirow{2}{*}{ SEM } & \multicolumn{3}{|c|}{ Main effect of } \\
\hline & $\mathbf{N}$ & $\mathbf{L}$ & OL:OI:OV & 4L:1I:1V & 4L:1I:3V & & PC & BCAA & PC $\times B C A A$ \\
\hline \multicolumn{10}{|c|}{ On $14 \mathrm{~d}$ of age } \\
\hline Heart & 0.70 & 0.71 & 0.69 & 0.73 & 0.69 & 0.016 & ns & ns & ns \\
\hline Liver & 3.16 & 3.37 & 3.21 & 3.28 & 3.31 & 0.069 & ns & ns & ns \\
\hline Pancreas & $0.37^{b}$ & $0.42^{\mathrm{a}}$ & 0.37 & 0.42 & 0.40 & 0.010 & $\star \star$ & ns & ns \\
\hline Breast & 15.14 & 14.78 & 15.68 & 14.60 & 14.60 & 0.400 & ns & ns & ns \\
\hline Thigh & 11.32 & 11.62 & 11.58 & 11.68 & 11.24 & 0.078 & ns & ns & ns \\
\hline \multicolumn{10}{|c|}{ On $42 \mathrm{~d}$ of age } \\
\hline Heart & 0.51 & 0.52 & 0.52 & 0.54 & 0.49 & 0.016 & ns & ns & ns \\
\hline Liver & 1.83 & 1.77 & 1.92 & 1.71 & 1.77 & 0.043 & ns & ns & ns \\
\hline Pancreas & 0.17 & 0.18 & 0.18 & 0.17 & 0.18 & 0.007 & ns & ns & ns \\
\hline Breast & 23.82 & 22.92 & $24.34^{\mathrm{a}}$ & $22.50^{b}$ & $23.24^{\mathrm{ab}}$ & 0.163 & ns & * & ns \\
\hline Thigh & 16.24 & 16.10 & 16.14 & 16.06 & 16.32 & 0.083 & ns & ns & ns \\
\hline
\end{tabular}

SEM, standard error of the mean.

1) The values are means of the four replicates with two birds per treatment.

2) PC, crude protein content of starter diets; BCAA, added blends of branched-chain amino acids; N, starter diet (22\% to d 15) formulated with normal crude protein; L, starter diet formulated (20\% to d 15) with low crude protein; OL:Ol:OV, diet without of BCAA blends; 4L:1l:1V, diet added L-leucine, L-isoleucine, and L-valine at 1.0, 0.25, and $0.75 \mathrm{~g} / \mathrm{kg} ; 4 \mathrm{~L}: 1 \mathrm{l}: 3 \mathrm{~V}$, diet added L-leucine, L-isoleucine, and L-valine at 1.0, 0.25, and $0.75 \mathrm{~g} / \mathrm{kg}$.

a,b Within a row, means with different superscripts differ significantly $(p<0.05)$.

ns, nonsignificant; $p>0.05 ;{ }^{*} p<0.05 ; * \star p<0.01$. 
Table 5. The nutrient contents of breast and thigh meats of broilers fed starter diets with different levels of protein and blends of branched-chain amino acids under hot summer conditions

\begin{tabular}{|c|c|c|c|c|c|c|c|c|c|}
\hline \multirow{2}{*}{ Variable $^{1)}$} & \multicolumn{2}{|c|}{$\mathrm{PC}^{2)}$} & \multicolumn{3}{|c|}{$\mathrm{BCAA}^{2)}$} & \multirow{2}{*}{ SEM } & \multicolumn{3}{|c|}{ Main effect of } \\
\hline & $\mathbf{N}$ & $\mathbf{L}$ & OL:OI:OV & 4L:1I:1V & 4L:1I:3V & & PC & BCAA & PC $\times B C A A$ \\
\hline \multicolumn{10}{|l|}{ On $14 \mathrm{~d}$ of age } \\
\hline Dry matter & 26.76 & 27.84 & $29.09^{a}$ & $26.78^{\mathrm{ab}}$ & $26.04^{b}$ & 0.459 & ns & * & ns \\
\hline Protein & 21.58 & 22.37 & 21.69 & 22.56 & 21.67 & 0.335 & ns & ns & ns \\
\hline Ether extract & 0.77 & 0.90 & 0.97 & 0.66 & 0.84 & 0.138 & ns & ns & ns \\
\hline Dry matter & 24.74 & 25.16 & 24.33 & 25.51 & 25.01 & 0.295 & ns & ns & * \\
\hline Protein & $21.60^{\mathrm{a}}$ & $20.15^{b}$ & 20.07 & 21.70 & 20.85 & 0.293 & * & ns & ns \\
\hline Ether extract & 2.38 & 2.21 & 2.44 & 2.22 & 2.23 & 0.197 & ns & ns & ns \\
\hline Ash & 1.13 & 1.24 & 1.27 & 1.23 & 1.06 & 0.049 & ns & ns & ns \\
\hline \multicolumn{10}{|l|}{ On $42 \mathrm{~d}$ of age } \\
\hline Ash & 1.05 & 1.20 & 1.19 & 0.88 & 1.32 & 0.110 & ns & ns & ns \\
\hline \multicolumn{10}{|l|}{ Thigh meat } \\
\hline Dry matter & 25.12 & 25.07 & 23.89 & 25.94 & 25.46 & 0.236 & ns & $\star \star$ & $\star \star$ \\
\hline Protein & 21.97 & 22.18 & 21.85 & 21.89 & 1.59 & 0.191 & ns & ns & ns \\
\hline Ether extract & 1.37 & 1.60 & 1.40 & 1.59 & 1.15 & 0.116 & ns & ns & ns \\
\hline Ash & 1.12 & 0.90 & 0.85 & 1.07 & 1.12 & 0.075 & ns & ns & ns \\
\hline
\end{tabular}

SEM, standard error of the mean.

1) The values are means of the four replicates with two birds per treatment.

2) $\mathrm{PC}$, crude protein content of starter diets; BCAA, added blends of branched-chain amino acids; N, starter diet (22\% to d 15) formulated with normal crude protein; L, starter diet formulated (20\% to d 15) with low crude protein; OL:Ol:OV, diet without of BCAA blends; 4L:1l:1V, diet added L-leucine, L-isoleucine, and L-valine at 1.0, 0.25, and $0.75 \mathrm{~g} / \mathrm{kg} ; 4 \mathrm{~L}: 1 \mathrm{l}: 3 \mathrm{~V}$, diet added L-leucine, L-isoleucine, and L-valine at 1.0, 0.25, and $0.75 \mathrm{~g} / \mathrm{kg}$.

a,b Within a row, means with different superscripts differ significantly $(p<0.05)$.

ns, nonsignificant; $p>0.05 ; * p<0.05 ; \star \star ~ p<0.01$.

Table 6. The meat and liver colour values and meat water holding capacity of broilers fed starter diets with different levels of protein and blends of branched-chain amino acids under hot summer conditions

\begin{tabular}{|c|c|c|c|c|c|c|c|c|c|}
\hline \multirow{2}{*}{ Variable $^{1)}$} & \multicolumn{2}{|c|}{$\mathrm{PC}^{2)}$} & \multicolumn{3}{|c|}{ BCAA $^{2)}$} & \multirow{2}{*}{ SEM } & \multicolumn{3}{|c|}{ Main effect of } \\
\hline & $\mathbf{N}$ & $\mathbf{L}$ & OL:OI:OV & 4L:1I:1V & 4L:1I:3V & & PC & BCAA & PCXBCAA \\
\hline \multicolumn{10}{|c|}{ Breast meat } \\
\hline$a^{*}$ & 5.57 & 5.47 & 5.44 & 5.69 & 5.42 & 0.139 & ns & ns & ns \\
\hline$b^{*}$ & 6.07 & 5.66 & $6.10^{\mathrm{ab}}$ & $6.53^{\mathrm{a}}$ & $4.96^{b}$ & 0.238 & ns & $\star$ & ns \\
\hline WHC & $56.10^{a}$ & $53.13^{b}$ & 55.25 & 54.43 & 54.18 & 0.413 & $\star \star$ & ns & ns \\
\hline$a^{\star}$ & 8.70 & 8.07 & 8.32 & 8.12 & 8.72 & 0.219 & ns & ns & ns \\
\hline$b^{\star}$ & 7.13 & 6.09 & $5.81^{b}$ & $7.55^{\mathrm{a}}$ & $6.45^{\mathrm{ab}}$ & 0.252 & ns & * & ns \\
\hline WHC & $61.02^{a}$ & $59.32^{b}$ & 60.16 & 59.86 & 60.50 & 0.408 & $\star$ & ns & ns \\
\hline \multicolumn{10}{|l|}{ Liver } \\
\hline$L^{*}$ & 38.02 & 38.01 & 37.56 & 38.08 & 38.41 & 0.653 & ns & ns & ns \\
\hline
\end{tabular}

SEM, standard error of the mean; WHC, water holding capacity.

1) The values are means of the four replicates with two birds per treatment.

2) PC, crude protein content of starter diets; BCAA, added blends of branched-chain amino acids; N, starter diet (22\% to d 15) formulated with normal crude protein; L, starter diet formulated (20\% to d 15) with low crude protein; OL:Ol:OV, diet without of BCAA blends; 4L:1l:1V, diet added L-leucine, L-isoleucine, and L-valine at 1.0, 0.25, and $0.75 \mathrm{~g} / \mathrm{kg} ; 4 \mathrm{~L}: 11: 3 \mathrm{~V}$, diet added L-leucine, L-isoleucine, and L-valine at 1.0, 0.25, and $0.75 \mathrm{~g} / \mathrm{kg}$.

$a, b$ Within a row, means with different superscripts differ significantly $(p<0.05)$.

ns, nonsignificant; $p>0.05 ; * p<0.05 ; \star \star ~ p<0.01$. 
The effect of the branched-chain amino acids blends The BWG, FCR, and carcass weight of broiler chickens were not affected by the BCCA treatment at 14 and $42 \mathrm{~d}$ of age (Table 3). Breast yield was negatively affected by the 4L:1I:1V diet compared to the 0L:0I:0V diet ( $\mathrm{p}=0.041$; Table 4). At $14 \mathrm{~d}$ of age, the DM content of breast meat of the 0L:0I:0V broilers was higher compared to the 4L:1I:3V birds (Table 5). The $b^{*}$ values of the breast $(p=0.040)$ and thigh $(p=0.035)$ meats of the 4L:1I:1V broilers were higher than those of the 0L:0I:0V and 4L:1I:3V birds, respectively ( $\mathrm{p}<0.05$, Table 6). The liver $\mathrm{a}^{*}$ value in the $4 \mathrm{~L}: 1 \mathrm{I}: 1 \mathrm{~V}$ group was higher than those in other groups $(\mathrm{p}=0.040)$. The $4 \mathrm{~L}: 1 \mathrm{I}: 3 \mathrm{~V}$ broilers had higher $(\mathrm{p}=0.042)$ the proventriculus weight compared to the $0 \mathrm{~L}: 0 \mathrm{I}: 0 \mathrm{~V}$ and $4 \mathrm{~L}: 1 \mathrm{I}: 1 \mathrm{~V}$ birds at $14 \mathrm{~d}$ of age and had higher $(\mathrm{p}=0.047)$ the jejunum weight compared to the $4 \mathrm{~L}: 1 \mathrm{I}: 1 \mathrm{~V}$ birds on $\mathrm{d} 42$ (Table 7).

\section{The interaction effect of the studied factors}

There were interactions between factors for the weights of the whole gut, jejunum, ileum, large intestine and the DM content of thigh meat at $14 \mathrm{~d}$ of age and the FI, mortality and DM content and $\mathrm{L}^{\star}$ value of thigh meat at $42 \mathrm{~d}$ of age (Table 8). The FI and mortality of L4L:1I:1V broilers were lower than those of N4L:1I:1V birds ( $\mathrm{p}<0.05)$. At $14 \mathrm{~d}$ of age, the L4L:1I:1V and L4L:1I:3V diets increased the weight of whole gut compared to the L0L:0I:0V diet, whereas L4L:1I:3V increased the weight of jejunum compared to the L0L:0I:0V,
L4L:1I:1V, and N4L:1I:1V ( $p<0.05)$. The weights of ileum and large intestine and the DM content of thigh meat of the L0L:0I:0V broilers were higher than those of birds fed other diets, except for the N4L:1I:1V ( $\mathrm{p}<0.05)$. On $\mathrm{d} 42$, N4L:1I:3V increased the DM content of thigh meat compared to N0L:0I:0V, L0L:0I:0V, and L4L:1I:1V ( $p<0.05)$. The broilers fed with $\mathrm{N} 0$ diet had lower the thigh meat $\mathrm{L}^{\star}$ value than that of birds fed with N4L:1I:1V and L0L:0I:0V $(p<0.05)$.

\section{DISCUSSION}

The daily BWG (58.4 g) and FCR (1.84) of the $\mathrm{N}$ birds were quite below the standard ( $65.8 \mathrm{~g}$ and 1.68 , respectively) expected for mixed-sex broilers under controlled environment conditions [15]. This might be since the heat exposure impairs the intestinal morphology, appetite and consequently performance traits $[9-11,20]$ because the present study was conducted under warm summer conditions (average weekly indoor $32.8^{\circ} \mathrm{C} \pm 1.7^{\circ} \mathrm{C}$ temperature and $61.1 \% \pm 4.12 \%$ humidity). In agreement with Liu et al [21], our study revealed that the impact of heat stress could be mitigated partially by adjusting PCs of the diets as a nutritional practice. Irrespective of the BCAAs blends used, a higher final BW with similar FI and FCR was achieved in the L broilers. Our results indicated that the BWG, FI, and FCR of the broilers were not influenced by reduced CP $[16,21]$ or the dietary protein profile [9]. Therefore, our findings supported the idea that

Table 7. The relative weight ( $\mathrm{g} / 100 \mathrm{~g}$ body weight) of the gastrointestinal tract (gut) and its segments from broilers fed starter diets with different levels of protein and blends of branched-chain amino acids under hot summer conditions

\begin{tabular}{|c|c|c|c|c|c|c|c|c|c|}
\hline \multirow{2}{*}{ Variable $^{1)}$} & \multicolumn{2}{|c|}{$\mathrm{PC}^{2)}$} & \multicolumn{3}{|c|}{$\mathrm{BCAA}^{2)}$} & \multirow{2}{*}{ SEM } & \multicolumn{3}{|c|}{ Main effect of } \\
\hline & $\mathbf{N}$ & $\mathbf{L}$ & OL:OI:OV & 4L:1I:1V & 4L:1I:3V & & PC & BCAA & PC $\times B C A A$ \\
\hline \multicolumn{10}{|l|}{ On $14 \mathrm{~d}$ of age } \\
\hline Proventriculus & 0.82 & 0.80 & $0.74^{\mathrm{b}}$ & $0.80^{b}$ & $0.90^{a}$ & 0.009 & ns & * & ns \\
\hline Gizzard & 2.32 & 2.35 & 2.36 & 2.33 & 2.32 & 0.049 & ns & ns & ns \\
\hline Duodenum & 1.25 & 1.11 & 1.16 & 1.20 & 1.19 & 0.044 & ns & ns & ns \\
\hline Large intestine & 0.37 & 0.28 & 0.30 & 0.35 & 0.33 & 0.027 & ns & ns & * \\
\hline \multicolumn{10}{|l|}{ On $42 \mathrm{~d}$ of age } \\
\hline Whole gut & 7.81 & 7.74 & 7.72 & 7.72 & 7.88 & 0.201 & ns & ns & ns \\
\hline Proventriculus & 0.37 & 0.34 & 0.36 & 0.37 & 0.34 & 0.009 & ns & ns & ns \\
\hline Gizzard & 1.42 & 1.33 & 1.31 & 1.32 & 1.49 & 0.044 & ns & ns & ns \\
\hline
\end{tabular}

SEM, standard error of the mean.

1) The values are means of the four replicates with two birds per treatment.

2) PC, crude protein content of starter diets; BCAA, added blends of branched-chain amino acids; N, starter diet (22\% to d 15) formulated with normal crude protein; L, starter diet formulated ( $20 \%$ to d 15 ) with low crude protein; OL:Ol:OV, diet without of BCAA blends; 4L:11:1V, diet added L-leucine, L-isoleucine, and L-valine at 1.0, 0.25, and $0.75 \mathrm{~g} / \mathrm{kg} ; 4 \mathrm{~L}: 1 \mathrm{l}: 3 \mathrm{~V}$, diet added L-leucine, L-isoleucine, and L-valine at 1.0, 0.25, and 0.75 g/kg.

a,b Within a row, means with different superscripts differ significantly $(p<0.05)$.

ns (nonsignificant), $p>0.05 ; * p<0.05 ; * \star p<0.01$. 
Table 8. Interaction effect of different levels of protein and the branched-chain amino acids blends on relative gastrointestinal tract (gut) weight, feed intake, mortality and meat dry matter content in broilers under hot summer conditions

\begin{tabular}{|c|c|c|c|c|c|c|}
\hline Variable & NOL:OI:OV ${ }^{1)}$ & N4L:1I:1V ${ }^{1)}$ & N4L:1I:3V'1) & LOL:0I:0V ${ }^{1)}$ & L4L:1I:1V ${ }^{1)}$ & L4L:1l:3V'1) \\
\hline \multicolumn{7}{|l|}{ At $14 \mathrm{~d}$ of age } \\
\hline \multicolumn{7}{|c|}{ Relative weights (g/100 g BW) of ${ }^{2)}$} \\
\hline Whole gut & $15.09^{\mathrm{a}}$ & $14.70^{\mathrm{ab}}$ & $15.03^{\mathrm{a}}$ & $12.45^{\mathrm{b}}$ & $16.39^{\mathrm{a}}$ & $15.60^{\mathrm{a}}$ \\
\hline Jejunum & $3.60^{\mathrm{ab}}$ & $2.97^{\mathrm{bc}}$ & $3.60^{\mathrm{ab}}$ & $2.67^{c}$ & $3.20^{\mathrm{bc}}$ & $3.89^{a}$ \\
\hline lleum & $2.32^{\mathrm{a}}$ & $2.04^{\mathrm{ab}}$ & $2.28^{a}$ & $1.57^{b}$ & $2.24^{a}$ & $2.33^{a}$ \\
\hline Large intestine & $0.42^{\mathrm{a}}$ & $0.42^{\mathrm{a}}$ & $0.28^{\mathrm{ab}}$ & $0.19^{b}$ & $0.28^{\mathrm{ab}}$ & $0.39^{a b}$ \\
\hline Feed intake $(\mathrm{g} / \mathrm{bird} / \mathrm{d})^{3)}$ & $107.65^{\mathrm{ab}}$ & $110.38^{a}$ & $105.69^{\mathrm{ab}}$ & $110.84^{\mathrm{a}}$ & $103.20^{b}$ & $109.92^{\mathrm{a}}$ \\
\hline Mortality (\%) & $6.25^{\mathrm{bc}}$ & $10.16^{\mathrm{a}}$ & $4.69^{c}$ & $9.38^{\mathrm{a}}$ & $5.21^{\mathrm{c}}$ & $7.81^{\mathrm{b}}$ \\
\hline Dry matter (\%) & $22.71^{b}$ & $27.15^{\mathrm{a}}$ & $25.29^{\mathrm{ab}}$ & $24.87^{b}$ & $24.73^{b}$ & $25.32^{\mathrm{ab}}$ \\
\hline$L^{*}$ value of thigh meat ${ }^{2)}$ & $58.17^{c}$ & $61.03^{\mathrm{ab}}$ & $58.85^{b c}$ & $62.06^{\mathrm{a}}$ & $59.36^{\mathrm{bc}}$ & $59.21^{\mathrm{bc}}$ \\
\hline
\end{tabular}

BW, body weight, DMC, dry matter content.

1) NOL:Ol:OV, the starter diets (22\% to d 15) with the normal protein content (PC), added L-leucine, L-isoleucine, and L-valine at zero (OL:0l:0V); N4L:1l:1V, the starter diets with the normal PC added L-leucine, L-isoleucine, and L-valine at 1.0, 0.25, and 0.25 (4L:1l:1V) g/kg of diet; N4L:1l:3V, the starter diets with the normal PC added L-leucine, L-isoleucine, and L-valine at 1.0, 0.25, and 0.75 (4L:1l:3V) g/kg of diet; LOL:0l:OV, the starter diets (20\% to d 15) with the low PC added L-leucine, L-isoleucine, and L-valine at zero; L4L:1l:1V, the starter diets with the low PC added L-leucine, L-isoleucine, and L-valine at 1.0, 0.25, and 0.25 (4L:1l:1V) g/kg of diet; L4L:1l:3V, the starter diets with the low PC added L-leucine, L-isoleucine, and L-valine at 1.0, 0.25, and 0.75 (4L:1l:3V) g/kg of diet.

2) The values are means of the four replicates with two birds per treatment.

3) The values are means of the four replicates with 32 birds per treatment.

${ }^{a-c}$ Within a row, means with different superscripts differ significantly $(p<0.05)$

low $\mathrm{CP}$ diets can contribute to the growth of broilers equal to that of normal CP diets $[1,3,10]$.

The effect of the PC on the FI, mortality and gut weights gut weights of the broilers were depended on the L:I:V ratios under summer conditions due to the interaction effect of the factors. Therefore, the BCAAs profile of the low CP diets under warm summer conditions had a beneficial effect on the FI and the livability of the broilers, as reported by Liu et al [21]. These findings indicated that the dietary CP level was probably not so important and the BCAAs profile of the diet was rather a more important factor due to the antagonistic impact between leucine and valine in the diet $[5,11,22]$ or antagonism among BCAAs [11]. Indeed, in the previous studies [5,22], feeding low CP diets with high leucine level decreased the FI of birds, since leucine and valine levels interacted positively with the FI [22]. Also, antagonisms between BCAAs may increase valine requirement, causing broilers to enhance FI [11]. This may explain why there was an interaction between factors for FI. In the present study, however, no benefits were detected for triple the supply of valine in the BCCAs blends in terms of the BWG and FCR in the broilers. Pereira et al [11] observed that there is a positive linear and quadratic effect of valine concentrations on FI and BWG, respectively, in growing male broilers in the hot-climate region.

Our results on the BWG and FCR indicated that the impact of the BCAAs on these variables might not vary by the amount of valine in the BCAAs or the dietary $\mathrm{CP}$, as reported by Miranda et al [7]. However, these results are disagreement with previous some studies $[6,22]$ in which broiler perfor- mance was positively affected by valine supplementation. The differences among the previous studies and the present study may be related to the fact that the relationships among BCAAs contribute to the differences in the AA ratios such as valine to lysine [22-24] and/or digestible valine requirements differ for maximum performances and breast yield in broilers fed low-CP diet during the starter phase $[11,13,14]$. Potença et al [23] reported that a valine to lysine ratio of $66 \%$ is sufficient to maximize the performance of broilers from 1 to $14 \mathrm{~d}$ of age. However, in a recent study [6], the optimal digestible valine to lysine ratio in the starter phase $(0$ to $12 \mathrm{~d}$ ) has been reported as 0.78 for BWG and 0.80 for FCR. Indeed, the valine levels and valine to lysine ratios $(0.79,0.81$, and 0.85 for $0 \mathrm{~L}: 0 \mathrm{I}: 0 \mathrm{~V}, 4 \mathrm{~L}: 1 \mathrm{I}: 1 \mathrm{~V}$ and $4 \mathrm{~L}: 1 \mathrm{I}: 3 \mathrm{~V}$ groups) of the starter diets in the present study were higher than the recommendations in the previous studies [6,22-24].

In the present study, the final BW was less compared to the standard [15] due to the negative impact of heat stress on the growth performance $[10,11]$, which also may be an explanation for the reduced dressing percentage [3]. Although dietary protein has not affected carcass yield [9] and breast yield [22] in broilers, in some studies, broilers fed the low$\mathrm{CP}$ diet have had lower breast and drumstick yields compared to high- or medium-CP fed birds [3,9]. These reports and our findings indicate that the maximum breast yield requires a normal-CP diet. Furthermore, the valine requirements for the proliferation of muscle cells in broiler chickens at early stages of growth may be altered by high summer temperature $[4,13]$. These discrepancies may be due to the breed 
and age of experimental birds, the valine- and isoleucineto-lysine ratios $[6,23,24]$ and the quality of the ingredients of diets or the severity and duration of high temperature $[1,11,25]$. Indeed, the previous studies dealing with AAs fortification to low-CP diets in poultry have been carried out using high quality diets under a controlled environment or in confined systems [5-7].

As known, the chemical composition of broiler skeletal muscles can be affected by nutrition. In the present study, the $\mathrm{L}$ diet decreased the protein content of thigh meat from broiler chicks on d 14, as was reported by Furlan et al [10]. However, this effect was not reflected in the proximate analysis of breast and thigh meats at the end of the trial. The gut of the newly hatched chick is in a process of development and maturation during the first few weeks of life. The development of gut in broiler chicks can, thus, be affected by the blends of BCAAs having different valine contents during this period, as reported by Norouzian et al [2]. Our results on the development of whole gut may be explained by the fact that the efficiency of dietary protein utilization in poultry depends partly on the features of the gut [9]. The changes in the weights of proventriculus, jejunum and cecum may be due to the proteinogenic functions of the BCAAs [26]. The proteinogenic effects of the BCAAs with different valine contents were not confirmed to the results on the breast and thigh meats, because BCAAs in the present study decreased the breast meat yield, but did not affect thigh meat yield. Therefore, these results indicated that supplementation of valine was not critical in promoting higher carcass and breast weights or yields in broilers, as reported by Agostini et al [24]. These results may be related to negative interactions between supplemental valine and isoleucine $[5,11,22]$.

In poultry, the liver, one of the most active organs, and the studied muscles, the tissue of the highest economic value, are metabolically important organs and tissues. The CIELab values of meats and liver, an indicator of the physiological condition of birds [12], were within previously reported normal range [27]. In the present study, no assessment was done to study tissue energy metabolism. The results concerning the liver, breast and thigh meats indicate that there is a difference in the metabolic energy utilization efficiency of the BCAAs blends with different valine contents in growing birds under summer conditions. Imanari et al [28] reported that the BCAAs profile of broiler diets, especially those with high valine and isoleucine improved the meat quality. One of the main determinants of WHC in meat is post-mortem protein denaturation [29]. A reduction in the WHC causes a decrease in $L^{*}$ and $a^{\star}$ values and an increase in $b^{*}$ value of poultry meats $[27,30]$. In the present study, dietary BCAAs with different valine contents caused a change in the WHC of the studied meats. Although there was an interaction between factors for the $\mathrm{L}^{\star}$ value of thigh meat [27], the higher
WHC of breast and thigh of broiler chickens fed with low-CP starter diet did not affect the $\mathrm{L}^{*}$ value of the broiler meats. This indicates that dietary protein and BCAAs levels did not affect the CIELab and WHC values of the meat in broilers fed the same diet throughout the growth phase. The changes in the $b^{*}$ values of breast and thigh meats may be related to a muscle wastage [30]. The increase in the redness value of liver from 4L:1I:1V broilers may be associated with changes in some metabolites and nutrients [26,27] due to participate of BCAAs to some metabolic pathways such as lipolysis, lipogenesis and glycolysis [26].

\section{CONCLUSION}

In the present study, the BCAAs blends supplementation failed to improve FCR as a result of feeding ideal or low protein under summer conditions. Increasing valine in dietary BCAAs blends does not cause a measurable variation in nutritional and visual meat qualities. Also, feeding low-CP diets at the first $14 \mathrm{~d}$ of the life of broilers, irrespective of the BCAAs blends, could result in a similar performance. However, supplementation of valine is not critical in promoting higher carcass and breast weights or yields in broilers. The present study can provide a basis for research into the effects of dietary CP supplemented or not with blends of BCAAs on broiler chickens under hot summer conditions. However, to well define the response of broilers to low-CP diets supplemented or not with blends of BCAAs having different valine contents and other essential AAs requires further investigation in normal- and hot-climatic regions.

\section{CONFLICT OF INTEREST}

We certify that there is no conflict of interest with any financial organization regarding the material discussed in the manuscript.

\section{ACKNOWLEDGMENTS}

This study was funded by the Scientific Research Fund of the Eskisehir Osmangazi University (2017-23D04). We would especially like to thank Dr A. V. Garipoglu from the Department of Animal Science, Faculty of Agriculture, Ondokuz Mayis University for the scientific suggestions and editing of English in the manuscript.

\section{REFERENCES}

1. Kamran Z, Sarwar M, Nisa M, et al. Effect of low levels of dietary protein on growth, protein utilisation and body composition of broiler chicks from one to twenty-six days of age. Avian Biol Res 2008;1:19-25. https://doi.org/10.3184/17581 


\section{$5508 \times 336639$}

2. Norouzian H, Alirezaei M, Dezfoulian O, Taati M. The effects of post-hatch feeding with betaine on the intestinal development of broiler chickens. Braz J Poult Sci 2018;20:403-12. https://doi.org/10.1590/1806-9061-2017-0468

3. Widyaratne GP, Drew MD. Effects of protein level and digestibility on the growth and carcass characteristics of broiler chickens. Poult Sci 2011;90:595-603. https://doi.org/10.3382/ ps.2010-01098

4. Buwjoom T, Yamauchi K, Erikawa T, Goto H. Histological intestinal alterations in chickens fed low protein diet. J Anim Physiol Anim Nutr 2010;94:354-61. https://doi.org/10.1111/ j.1439-0396.2008.00915.x

5. Ospina-Rojas IC, Murakami AE, Duarte CRA, et al. Leucine and valine supplementation of low-protein diets for broiler chickens from 21 to 42 days of age. Poult Sci 2017;96:91422. https://doi.org/10.3382/ps/pew319

6. Allameh S, Toghyani M. Effect of dietary valine supplementation to low protein diets on performance, intestinal morphology and immune responses in broiler chickens. Livest Sci 2019;229:137-44. https://doi.org/10.1016/j.livsci.2019. 09.025

7. Miranda DJA, Vieira SL, Favero A, Angel CR, Stefanello C, Nogueira ET. Performance and meat production of broiler chickens fed diets formulated at different crude protein levels supplemented or not with L-valine and L-isoleucine. Anim Feed Sci Technol 2015;206:39-47. https://doi.org/10.1016/ j.anifeedsci.2015.04.018

8. Brosnan JT, Brosnan ME. Branched-chain amino acids: enzyme and substrate regulation. J Nutr 2006;136:207-11. https://doi.org/10.1093/jn/136.1.207S

9. Laudadio V, Dambrosio A, Normanno G, et al. Effect of reducing dietary protein level on performance responses and some microbiological aspects of broiler chickens under summer environmental conditions. Avian Biol Res 2012;5: 88-92. https://doi.org/10.3184/175815512X1335018071 3553

10. Furlan RL, Faria Filho DE de, Rosa PS, Macari M. Does lowprotein diet improve broiler performance under heat stress conditions? Braz J Poult Sci 2004;6:71-9. https://doi.org/10. 1590/S1516-635X2004000200001

11.Pereira TVS, Névoa ML, Vieites FM, et al. Valine requirement of broilers raised in hot-climate region. In: Proceedings of the 55th Annual Meeting of the Brazilian Society of Zootechnics, 28th Brazilian Congress of Zootechnics 2018; 2018 Aug 27-30: Goiânia, GO, Brazil. Zootecnia Brasil; 2018. pp. 1.

12. Kop-Bozbay C, Ocak N. In ovo injection of branched-chain amino acids: embryonic development, hatchability and hatching quality of turkey poults. J Anim Physiol Anim Nutr 2019; 103:1135-42. https://doi.org/10.1111/jpn.13111

13. Nascimento GR, Murakami AE, Ospina-Rojas IC, Diaz-Vargas M, Picoli KP, Garcia RG. Digestible valine requirements in low-protein diets for broilers chicks. Braz J Poult Sci 2016; 18:381-6. https://doi.org/10.1590/1806-9061-2015-0162

14.Kaplan M, Yildiz G. The effects of dietary supplementation levels of valine on performance and immune system of broiler chickens. J Agric Crop Res 2017;5:25-31.

15. Aviagen. Ross 308 Broiler: Nutrition Specifications. Newbridge, Scotland, UK: Aviagen Ltd.; 2014.

16. Oliveira WP de, Oliveira RFM de, Donzele JL, et al. Dietary crude protein reduction on growth and carcass performance of 22 to 42-day-old broilers reared under different temperatures. Rev Bras Zootec 2013;42:599-604. https://doi.org/10. 1590/S1516-35982013000800010

17. Mabelebele M, Norris D, Brown D, Ginindza MM, Ngambi JW. Breed and sex differences in the gross anatomy, digesta $\mathrm{pH}$ and histomorphology of the gastrointestinal tract of gallus gallus domesticus. Braz J Poult Sci 2017;19:339-46. https://doi.org/10.1590/1806-9061-2016-0275

18. AOAC. Official methods of analysis. 19th ed. Arlington, VA, USA: Association of Official Analytical Chemists; 2007.

19. Castellini C, Mugnai C, Dal Bosco A. Effect of organic production system on broiler carcass and meat quality. Meat Sci 2002;60:219-25. https://doi.org/10.1016/S0309-1740(01) 00124-3

20. Kim JH, Lee HK, Yang TS, Kang HK, Kil DY. Effect of different sources and inclusion levels of dietary fat on productive performance and egg quality in laying hens raised under hot environmental conditions. Asian-Australas J Anim Sci 2019; 32:1407-13. https://doi.org/10.5713/ajas.19.0063

21.Liu QW, Feng JH, Chao Z, et al. The influences of ambient temperature and crude protein levels on performance and serum biochemical parameters in broilers. J Anim Physiol Anim Nutr 2016;100:301-8. https://doi.org/10.1111/jpn. 12368

22. Ospina-Rojas IC, Murakami AE, Duarte CRA, Pozza PC, Rossi RM, Gasparino E. Performance, diameter of muscle fibers, and gene expression of mechanistic target of rapamycin in pectoralis major muscle of broilers supplemented with leucine and valine. Can J Anim Sci 2019;99:168-78. https:// doi.org/10.1139/cjas-2018-0020

23.Potença A, Murakami AE, Ospina-Rojas IC, Fernandes JIM. Digestible valine-to-lysine ratio in diets for broiler chickens. Rev Mex Cienc Pecu 2015;6:25-37.

24. Agostini PS, Santos RR, Khan DR, Siebert D, van der Aar P. The optimum valine: lysine ratios on performance and carcass traits of male broilers based on different regression approaches. Poult Sci 2019;98:1310-20. https://doi.org/10.3382/ ps/pey454

25. Habashy WS, Milfort MC, Adomako K, Attia YA, Rekaya R, Aggrey SE. Effect of heat stress on amino acid digestibility and transporters in meat-type chickens. Poult Sci 2017;96: 2312-9. https://doi.org/10.3382/ps/pex027

26.Zhang S, Zeng X, Ren M, Mao X, Qiao S. Novel metabolic 
and physiological functions of branched chain amino acids: a review. J Anim Sci Biotechnol 2017;8:10. https://doi.org/ 10.1186/s40104-016-0139-z

27. Bayyurt L, Akdag A, Tirink C. Canonical correlation analysis for estimation of relationships between some characteristics and color of broiler meat. IOSR J Agric Vet Sci 2018;11:615.

28. Imanari M, Kadowaki M, Fujimura S. Regulation of tasteactive components of meat by dietary branched-chain amino acids; effects of branched-chain amino acid antagonism. $\mathrm{Br}$
Poult Sci 2008;49:299-307. https://doi.org/10.1080/00071660 802155080

29. Bowker B, Zhuang H. Relationship between water-holding capacity and protein denaturation in broiler breast meat. Poult Sci 2015;94:1657-64. https://doi.org/10.3382/ps/pev120

30. Azad MAK, Kikusato M, Maekawa T, Shirakawa H, Toyomizu M. Metabolic characteristics and oxidative damage to skeletal muscle in broiler chickens exposed to chronic heat stress. Comp Biochem Physiol A Mol Integr Physiol 2010;155:4016. https://doi.org/10.1016/j.cbpa.2009.12.011 